\title{
GCU
}

Glasgow Caledonian

University

University for the Common Good

\section{Virtually a drug scare: mephedrone and the impact of the internet on drug news transmission}

\author{
Forsyth, Alasdair
}

Published in:

International Journal of Drug Policy

DOI:

10.1016/j.drugpo.2011.12.003

Publication date:

2012

Document Version

Author accepted manuscript

Link to publication in ResearchOnline

Citation for published version (Harvard):

Forsyth, A 2012, 'Virtually a drug scare: mephedrone and the impact of the internet on drug news transmission', International Journal of Drug Policy, vol. 23, no. 3, pp. 198-209. https://doi.org/10.1016/j.drugpo.2011.12.003

\section{General rights}

Copyright and moral rights for the publications made accessible in the public portal are retained by the authors and/or other copyright owners and it is a condition of accessing publications that users recognise and abide by the legal requirements associated with these rights.

Take down policy

If you believe that this document breaches copyright please view our takedown policy at https://edshare.gcu.ac.uk/id/eprint/5179 for details of how to contact us. 
Virtually a Drug Scare:

Mephedrone and the impact of the Internet on drug news transmission

Dr Alasdair J M Forsyth (PhD)

Scottish Centre for Crime \& Justice Research

Room K301 Buchanan House

Institute for Society \& Social Justice Research

Glasgow Caledonian University

Glasgow, Scotland, G4 0BA

Alasdair.Forsyth@gcal.ac.uk

$\mathrm{T}+44(0) 1413318301$

F +44 (0) 1413313636

Acknowledgement Claire Lightowler for Google advice 


\section{Virtually a Drug Scare: \\ Mephedrone and the impact of the Internet on drug news transmission}

Introduction: On the $16^{\text {th }}$ April 2010 the drug mephedrone was outlawed in the UK. This followed news media reports of deaths linked to the drug. In many respects the mephedrone scare represented a familiar pattern of drug framing and legislative reaction. However, the mephedrone scare took place in the era of online news transmission. Methods: To quantify the mephedrone scare the Google Internet search-engine's Trends and News applications were monitored from when the first death was attributed to the drug until one year after it was banned. Findings: Web interest in buying mephedrone peaked when online news stories reported deaths from the drug. Eighteen alleged mephedrone deaths were identified from online news. The fatalities which received the most Internet traffic subsequently proved false-alarms. Online interactive media widened access to alternative explanations of these alleged mephedrone deaths. Conclusion: It is contended that the advent of the Internet accelerated and inflated the mephedrone scare, but also that online media allowed [web] user-generated information transmission, rather than simple dissemination by news media to audience, fostering competing discourses to stock drug scare themes as they emerged.

Keywords: mephedrone, media, drug scare, ecstasy

Words: 7,744 (including quotes) 


\section{Introduction}

\section{Familiar drug scares}

Drug scares follow a familiar pattern (Jenkins, 1999; Kohn, 1997; Newcombe, 1998). At first a new drug of concern is newsworthy for its novelty value, perhaps only being reported in esoteric publications (e.g. music press) or equivalent specialist sections of mainstream titles (Braden, 1973; Forsyth 2001a). Should events (e.g. increased prevalence or a high profile case) lead to the drug concerned breaking into the mainstream press, then the drug is invariably constructed as a problem (Levine \& Reinarman, 1989; Young, 1973) with subsequent stories being reported in a disproportionate way (Goode, 2008). After this first news story peak, the media report their own campaigns against the drug, bringing onside politicians, researchers and other moral entrepreneurs in demanding a legislative response (Bean, 1993; Reinarmann \& Duskin, 1992). Rather than a 'moral panic' (Cohen, 1972) this process of 'drug framing' may be seen as news being manufactured in a "deliberate and rationale way" by the media and these other actors (Cornwell \& Linders, 2002). Once a policy reaction has taken place, the volume of news about the drug subsides, even when concerning real stories which may have been exaggerated in the past (Forsyth 2001a; Goode, 2008). There may be some counter-reaction from sections of the press, especially if prior stories are subsequently proven unfounded, although this may also be subject to critical reaction (Murji, 1998) ensuring that any amendment to drug policy is unlikely to be reversed. This pattern may vary in duration and scale. For example, of two 1990s UK scares, one concerning alcopops lasted at most four years (Forsyth, 2001a), while one concerning ecstasy persisted throughout the decade, going mainstream in the 1988 'Acid House Panic' (Davies \& Ditton, 1990; Edwards, 1989), and peaking with the reaction to the death of Leah Betts in 1995 (Collin, 1997; Manning, 2006). 
During the ecstasy scare reported deaths and associated harms tended to involve disproportionate numbers of teenagers or females, often portrayed as first-time experimenters (Forsyth 2001b; Manning, 2006; Taylor, 2008). This is what Reinarman (1997, p.101) calls the "routinization of caricature". It does not reflect the demographics of actual drug-related deaths in the community, who tend to be male, multi-drug experienced, and are rarely teenagers (Graham, 2010; ONS, 2011; Wong \& Alexander, 1991).

Drug scares tend to focus on the 'moral dimension' or 'human interest angle' (Goode, 2008) of individual tragedies rather than the proportionate threat which the substance concerned may actually present in public health terms. Drug scares also tend to involve the same harms being reported, regardless of the pharmacology of the substance concerned. Goode (2008) lists many of these alleged harms, arguing that the more stereotypical, false or scary these are, the more the public will believe that such reports are true, even when compared to empirically verified harms. Some of the alleged harms from previous drug scares have included sudden deaths, violence, self-harm, brain damage, cognitive deficits, unknown 'long-term effects', unique syndromes (identified by specially designed tests), chromosome or synapse damage (only visible to experts using specialist equipment, e.g. electron microscopes or PET scans), blindness, baldness and impotence or sterility. Jenkins (1999, p.4) describes a "timeless" process, whereby each new drug of concern has the same rhetoric applied as previous ones.

The media raising awareness about a new drug of concern may be unhelpful, because as well as diverting attention from drugs which have a greater impact on public health (e.g. alcohol), this is effectively advertising, providing what Farrell (1989) termed the 'the oxygen of publicity' in the case of ecstasy. If the media's intention was to prevent drug use, or harm, then their reports may risk a 'boomerang effect ${ }^{1}$, , that is where actions have the opposite effect to what was 
intended. As The ${ }^{2}$ Guardian, a UK national newspaper, affirmed "Young people know that taking ecstasy (or whatever this year's successor is called) can be, and quite often is, fatal" (Berlins, 2006). Three years later that successor arrived - mephedrone.

\section{Mephedrone as a virtual drug scare}

In November 2009 several factors (rules of relevance) coincided to make mephedrone perfect for a traditional drug scare. The alleged death of a 14 year-old schoolgirl from the drug fitted the Leah Betts or Anna Wood model (Dillon et al, 1996; Manning 2006) of 'mainstream over marginality' (Taylor, 2008). Her death took place in a town (Brighton) where the recent highprofile death of another female student, involving the drug gamma-Butyrolactone (GBL), had led to that substance being banned at that time (enforced 23/12/09), though unlike that substance, the media reported mephedrone with a catchy nickname - "meow" (Measham et al, 2010; Silverman, 2010). Also, the mephedrone 'Brighton death' happened three weeks after the UK government had controversially sacked its leading drug advisor, from the Advisory Council on the Misuse of Drugs (ACMD), in a dispute over the classification of ecstasy (Dyer, 2009; Dixon, 2009). Finally, like previous drug scares (e.g. ecstasy with raves/nightclubs) mephedrone was associated with another supposed threat to young people - the Internet.

The following extract from the UK's largest circulation (hardcopy) daily newspaper, contains many of these themes, and marks the birth of the mephedrone drug scare.

\section{"DEAD TEEN 'TOOK PARTY DRUG'3",}

"Fun-loving Gabi Price suffered cardiac arrest after falling ill at a house party. A neighbour yesterday claimed the student had taken the clubbers' drug - which can be bought legally - mixed with illegal ketamine. Meow meow is the street name for mephedrone - sold legally online as PLANT FOOD for as little as $£ 10$ a gram." (The Sun, 24/11/09) 
Although many traditional drug scare themes were duly attributed to mephedrone by the media, unusually these emerged within a few weeks (as did the political reaction them), for example reports of the drug causing impotence and baldness.

\section{"Meow Meow in Impotence Link}

...Professor Mann said meow meow was similar to a drug used in Somalia called khat which has caused impotence. He said: "Could the dangers of this drug have been predicted? Of course they could." (The Sun, 01/04/10, Haywood, 2010a)

"Despairing Holly Smith, 20, became emaciated and clumps of her HAIR fell out after she got hooked on the lethal substance known as Meow Meow." (The News of the World $^{4}, 6 / 2 / 10,2010$ a)

What was different about the mephedrone scare was that it took place during the era of digital interactive media. Previous research into drug scares has been concerned with traditional news media, specifically the press (i.e. newspapers) or broadcast media (TV, radio). In these, the media were able to impart their views about a new drug of concern as the "core disseminator of local and national perspectives" (Cornwell \& Linder, 2002). Although the public may not have been entirely passive in this process (e.g. those who did not agree could send a letter to a newspaper in the hope it would be published) there was relatively less scope for dissenting voices to be heard. In recent years the advent of the Internet as a news source has changed this traditional pattern of dissemination (Mitchelstein \& Bockzkowski, 2009) and has questioned how social science should research the news media (Riesch, 2010). For traditional news media, the Internet has opened a fresh channel capable of reaching an ever expanding audience. The flip-side of this being that the Internet also allows the public access to a range of competing news sources including international, local and non-traditional media sources. Thus for example, through publication of an online edition, an article in a local newspaper can potentially be instantly accessible to a global readership, persisting in cyberspace long after the equivalent limited circulation hardcopy edition has expired. Additionally the Internet has 
interactive properties which allow individuals to respond to online information, by either 'forwarding' it (via e-mail or Twitter) or by transmitting their own version of events ('usergenerated content'), via blogs, online forums, social networking sites or by posting comments about (drug) stories directly under these on news media sites (although these may be vetted or removed by moderators). Thus mephedrone was potentially subject to different forms of amplification, reaction and counter-reaction to previous drug scares.

With mephedrone being marketed legally online, uniquely while still providing the 'oxygen of publicity' for this "killer net drug meow meow" (The Metro, 04/12/09), the press could also inform readers where they might buy it - over the Internet. This connection could be made either directly (e.g. news reports that the drug could be bought via social-networking or Internet auction sites) or indirectly/interactively, for example by automated ads for mephedrone appearing as pop-ups alongside stories of supposed harms, as is illustrated by the following online press reports retrieved by monitoring Google News.

"Youngsters can order club drug Mephedrone - also known as "bubble", "drone", "bounce" or "meow meow" - via websites like Facebook and get it delivered to their door the same day." (Daily Mirror, 07/03/10, Payne, 2010)

"Gabrielle Price, a 14-year-old girl from Hastings, died in November 2009 after a night when she had taken the drug. The newspapers reported the tragedy but, again, the automatically generated Google ads beneath the reports showed people exactly where they could buy this new, legal drug. It had gone viral." (The Mail on Sunday, 25/04/10, reprinted in Power \& Parry, 2010)

\section{Aims}

This paper aims to use Internet tools to quantify the mephedrone scare. Firstly to investigate whether news reports attributing harm to mephedrone (e.g. deaths) precipitated increases in web searches for the drug (e.g. where to buy it). It was hypothesised that interest in 
mephedrone (as measured by web searches) would be greatest following increased online news reports concerning the drug, such as high profile fatalities. Secondly this paper will investigate the nature and extent of online news stories concerning alleged mephedrone-related deaths. To this end, every death attributed to the drug identified by an online news-aggregator during the scare was compared. It was hypothesised that deaths which most closely fitted the traditional drug scare model (e.g. first-use experimenting teenagers or females) would receive the most disproportionate media attention (e.g. in terms newsworthiness or inaccuracy) and that this disproportionality would vary between online sources (e.g. national and local newspapers).

\section{Methods}

Traditionally research into drug news reporting has involved quantitative or qualitative (content) analysis of samples of newspapers or broadcast channels over a specific time and place (e.g. Belackova et al, 2011; Gould, 1996; Jones et al, 2008; Loughborough Communications Research Centre, 2010; Nichols, 2011). Such studies are labour-intensive, yet limited in scale (restricted to say one country) and have the potential for subjectivity and experimental error. Quantitative studies have involved counting news stories on databases/archives, measuring column inches or weighing newsprint clippings devoted to drugs. Qualitative research is often contemporaneously (sub)sampled and might be similarly criticised in regards of such studies objectivity and representativeness.

In a break with tradition, this article examines drug news published online. This was achieved by utilising research-friendly applications of the Google search-engine (for other examples of this method see Breyer \& Eisenberg, 2010; Breyer et al, 2011; Carneiro \& Mylonakis, 2009; Choi \& Varian, 2009; Rech, 2007; Seifter et al, 2010). Firstly, the Google Trends application was used to produce a series of time-trend graphs quantifying mephedrone-specific online 
activity. This application calculates contemporaneous trend graphs of both the amount of searches made on the Google search-engine for any search word/term, in this case "mephedrone", together with how much news coverage that word/term has been receiving (news reference volume). Google Trends also generates links to news headlines (citations) at breakpoints on these graphs. These graphs are not absolute but show the relative number of searches over time. The function also provides an indication of which geographical areas (countries and cities) searches for the trending word (e.g. "mephedrone") are most often being made from, as well as the most common related search terms (e.g. "mephedrone death"). Additionally the Google Insights option allows graphical comparisons to be made between search terms (e.g. "mephedrone death" with "mephedrone buy"). Next, the Google News newsaggregator was used to filter-out news stories concerning the word "mephedrone" between 26/11/09 (the start of the scare) and until one year after the drug was banned. Over this period all news published online concerning the drug was read chronologically, emergent themes identified and quotes illustrative of current news as the scare developed were extracted. Secondly, monitoring Google News over this period allowed all UK mephedrone deaths reported online to be identified. Google Advanced Search was then used to quantify online activity related to each of these fatalities (i.e. "Mephedrone AND [deceased's name]").

Using Google as research tool has a number of limitations. Firstly Google is only one searchengine. The returns from any search-engine are dependent on the parameters which it uses to search the web. So, for example, Google News may only return stories from a selection of, what it deems to be, online news story providers. Google Trends are normalised, meaning that rather than return the absolute number of searches carried out for a term (e.g. mephedrone), it shows the relative number over time, expressed as a proportion of the highest search volume received (http://www.google.ca/intl/en/trends/about.html\#7). The clarity of graphics returned 
by Google Trends are of limited web-resolution size. The total number of relevant searches identified may also be influenced by the search term itself, such as whether it has alternate spellings, an acronym or nickname (e.g. mephedrone, M-cat, meow or miaow).

However, Google is the most used internet search-engine, and although its' full list of sources are not known outside of Google, their website states that their news-aggregator watches 4,500 English language news sites (http://news.google.co.uk/intl/en_uk/about_google_news.html). Google Trends are updated daily, and for the purposes of this paper, when comparing the time trends for news mephedrone events to web searches for the drug, the actual numbers involved on each plot are less important than the ability to demonstrate a relative, temporal, relationship between these.

There are many advantages to this approach over traditional media sampling. What Google returns is not influenced by sampling decisions made by the researcher, and relevant stories can be retrieved later and read in their entirely, by any reader (e.g. of the references in this manuscript). This is not possible with samples of newspaper clippings or recordings filed in an author's office, with unpublished data transcripts held on software packages in institutions, where the reader has to trust the researchers' coding, interpretation and selection of illustrative quotes. Google returns are global, in this case picking up newspaper stories about mephedrone from around the world, ranging from local newspapers to international news agencies. This made it possible to compare the content different accounts of the same news event (e.g. an alleged mephedrone death) between say national titles and the online edition of the local newspaper where that event took place. Finally, this method was particularly salient for investigating mephedrone as it was widely acknowledged that users learnt about the drug from Internet sources (Davey et al, 2010; Newcombe, 2009; Van Hout \& Brennan, 2010) and 
crucially because this drug was being sold online (Home Office, 2010; Measham et al, 2010; Power, 2009).

\section{Findings}

The first section of these findings quantifies the mephedrone scare over its life-span via results obtained from Internet (Google) search applications. The second section investigates the nature and extent (newsworthiness) of all alleged mephedrone deaths identified during these searches.

\section{Measuring the time-line of a virtual drug scare}

Evidence in support of the hypothesis that increased news reports increased interest in mephedrone was retrieved by using Google Trends. Figure 1 is a screenshot of Google Trends charting the previous 12 months of the search word "mephedrone" from 25/02/10, with news reference volume plotted underneath. This shows that prior to the 'Brighton death', although the volume of web searches for mephedrone was increasing, relatively little press coverage concerning the drug had been identified by Google, with only an example from The New Musical Express (NME) cited. After the 'Brighton death' the volume of news coverage increased, as did the volume of web searches. Although Figure 1 does not provide the actual number of additional web searches made following the 'Brighton death', Google Trends indicate that the number doubled at this time.

\section{$<$ Figure 1>}

That raising awareness about this drug could act as an advertising campaign was acknowledged from this outset by both drug periodicals (e.g. Drink \& Drug News, 18/01/04, Gilliver, 2010) and the press themselves (Mail on Sunday, 25/04/10, Power \& Parry, 2010), including claims that media coverage of the Brighton death had stimulated sales. 
"The unintended consequence of this week's media coverage of mephedrone, a legal drug openly sold on the internet which may be implicated in the death of Gabrielle Price, a 14-year-old girl who collapsed at a party in Brighton last month, is that lots of suppliers have sold out." (Guardian, 05/12/09, Saner, 2009)

Within one month it was reported that the 'Brighton death' had been from 'natural causes'. This was highlighted in the online editions of the local newspapers from both the town where the schoolgirl had lived (Worthing) and the nearby town where she died.

"Worthing drug-scare teen died of natural causes. Teenager Gabi Price - whose death triggered fears over the dangers of 'legal highs' - died of natural causes, a coroner has revealed. A pathologist's report showed the 14-year-old died of broncho-pneumonia following a streptococcal A infection.” (Brighton Argus, 16/12/09, Parsons, 2009)

""SHE was branded a druggie, but she was just a little girl who died," Those are the moving words from the mother of Worthing teenager Gabi Price." (Worthing Herald, 22/12/09)

However, prior accounts of the 'Brighton death' blaming mephedrone were still available online, and for several months the deceased's name (and often image) continued to be used by the press as the 'poster' for fatalities linked to the drug - the 'Leah Betts of mephedrone'. This practice included articles published by more distant local press, for example in York's the Press (14/01/10, Fifield, 2010) and Birmingham's Sunday Mercury (07/03/10, Greatrex, 2010), by UK national and even international titles, for example Turkey's Hurriyet (23/12/09), the New Zealand Herald (02/03/11, Erikson \& Erikson, 2010) and China's Epoch Times (02/03/11, Jones, 2010).

"In the UK it claimed Gabi Price's life" (The News of the World ${ }^{4}, 06 / 02 / 10,2010 \mathrm{~b}$ )

"Gabrielle Price, a 14-year-old schoolgirl who died in the UK in November from a cocktail of drugs that included the legal high Meow Meow" (Times Of Malta, 03/04/10) 
Exceptionally, at this stage critical counter-reaction to this speculation, exaggeration and inaccuracy could be found in specialist (e.g. drugs or music) publications such as the NME.

"Despite the Daily Mail linking the tragic death of 14-year-old Gabrielle Price to mephedrone, a police report later identified the cause of death as bronchial pneumonia." (New Musical Express, 08/02/10, Wolfson, 2010)

The 'Brighton death' was used to initiate links to "a string of deaths", a term used by a string of newspapers, for example by Hereford Times (25/03/10, Ferguson 2010), The Daily Mail (26/03/10), The Mirror (28/03/10, Bulter, 2010), The Telegraph (29/03/10) and The Sun (29/03/10, Millard, 2010), linkage made by the press themselves.

“...its use has also been linked to the recent deaths of 14-year-old Gabi Price from Brighton, and Ben Walters, 18, from Hertfordshire. Det Con Willett said a string of deaths related to such drugs rang "alarm bells"." (Plymouth Western Morning News, $01 / 02 / 10)$

This pattern continued until 16/03/10.

"In November, Gabrielle Price, 14, of Worthing, West Sussex, died after allegedly taking the drug." (The Telegraph, 16/03/10, Britten \& Whitehead, 2010)

Over the $16 / 17^{\text {th }}$ March 2010 a story broke attributing mephedrone to the deaths of two teenage males - known by the name of the town where they died as the 'Scunthorpe 2'. Mephedrone became front-page news. For example the Metro's (17/03/11) headline "Meow kills 2 teenage friends" (a front-page which pictures of the deceased shared with a pub-chain's St Patrick's Day $^{5}$ promotion).

The effect of this double-fatality on Internet Google trending can be seen from Figures 2 to 5 . As shown by Figure 2, at this point (17/03/10) the number news reports concerning mephedrone identified by Google increased by an unprecedented proportion. As shown by the 
Figure 3, within days, a parallel increase in web searches for "mephedrone" was recorded. That is, the increased news reports shown on Figure 2 preceded the trebling in web searches shown by Figure 3. Figure 4 reveals that the rise in searches for "mephedrone buy" following these deaths dwarfed that following the 'Brighton death'. Figure 5, uses Google Insights, to show that spikes in searches for "mephedrone buy" and "mephedrone death" co-occurred at this time, and that this interest in buying was from the UK.

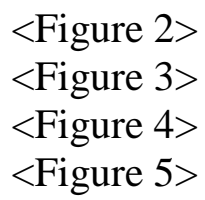

The 'Scunthorpe 2' deaths galvanised press campaigns to have the drug banned, with the news media citing the links they had made between mephedrone the 'string of deaths' and other harms, in the absence of any toxicological confirmation (e.g. The News of the World ${ }^{4}$, 21/03/10, 2010c). These press campaigns manufacturing consent for prohibition were predictably self-prophesying, as was their taking credit for the drug's subsequent prohibition (enforced 16/04/10).

“The Sun has launched a 'Ban Meow Now' campaign.”(The Sun, 19/03/10, Schofield, 2010)

"KILLER drug meow meow was outlawed today in a major victory for The Sun." (The Sun, 16/04/10, Wilson, 2010)

The increasing activity shown on Figures 2-5 happened during the 'wash-up' ${ }^{\text {, }}$ to the 2010 UK General Election (held 06/05/10). At this time it was interesting to note both the reported unanimity expressed by all politicians for prohibition, and that they were reportedly being informed about mephedrone by the news media, rather than their appointed drug advisers.

\section{"Northern Ireland Executive unanimous on mephedrone ban"} (BBC News, 26/03/10, 2010a) 
“...business secretary Lord Mandelson said the legality of it will be examined "very speedily, very carefully" following the news. He said he had previously never heard of it and that the government would take "any action that is justified to deal with this"'. (BBC News, 17/03/10, 2010b)

"Ban this kiddy crack now, Gordon [incumbent Prime Minister]. Our children need protection from mephedrone." (Daily Mirror ${ }^{7}, 22 / 03 / 10$, Parsons, 2010)

Following the ban, as can be seen from Figure 6, both web-searches for and news reports of "mephedrone", identified by Google, reduced to a level comparable to those prior to the scare, although the ban did not eliminate such activity.

\section{$<$ Figure 6>}

Once the decision had been made to ban mephedrone, dissenting discourses began to appear in journalistic blogs and other online news media (e.g. The Guardian 22/03/11, Brooker 2010, 24/05/11, Alderman, 2010; 05/08/10, Harris E., 2010; The Times, 01/04/10, Reid, 2010; The Observer 22/03/11, Townsend, 2010). These counter-reactions were bolstered one month after the ban $(18 / 05 / 10)$ when it was revealed that the 'Scunthorpe 2' had not used mephedrone.

"Two teenagers whose deaths were linked to the "legal high" mephedrone, prompting politicians to rush out a controversial ban, had not taken the drug, reports suggest. Leading scientists last night criticised the outlawing of the drug — before a single autopsy had been conducted - as an embarrassing fiasco borne of political opportunism and tabloid frenzy." (The Sunday Times, 28/05/10, Lister, 2010)

"When it was proven that Mephedrone was framed, and had become the Birmingham Six of drugs, no politician apologized. Nobody suggested repealing the ban." (USA Huffington Post, 30/09/10, Hari, 2010)

An inquest held in 2011 revealed the 'Scunthorpe 2' died from a combination of alcohol and methadone, detailed reporting of which could be found online via their local newspaper. 
"VERDICT of accidental overdose has been recorded in the case of Nick Smith, whose death helped lead to the banning of controversial drug mephedrone... But an inquest this morning found that $\mathrm{Mr}$ Wainwright had died of an accidental overdose of heroin substitute methadone, acting with alcohol intoxification." (Scunthorpe Telegraph, 25/01/11, 2011a)

As can be seen from Figure 6, the overall volume of news coverage confirming that mephedrone was not responsible for these fatalities is much less than coverage prior to the ban speculating that it was (see also Dargan \& Wood, 2011 pp82-83). Even cases where mephedrone was implicated in subsequent inquests received less coverage.

\section{Measuring newsworthy drug-related deaths from online media}

Google News searches from the start of the scare (26/11/09) till one year after the ban retrieved 18 alleged "mephedrone" deaths for named individuals. Table 1 lists these 18 deaths according to the estimated total number of web articles indentified by Google Advanced Search, for “mephedrone AND [deceased's name]” (conducted 23/06/11).

\section{$<$ Table $1>$}

Although these search returns are not restricted to online news items, as might be expected the 'Scunthorpe 2' and 'Brighton death' generated the most returns (cases \#1-3). In line with research into the ecstasy scare of the 1990s, half these Google newsworthy cases were teenagers and most were female. However it is striking that a 46 year-old male (a more typical drug fatality demographic) is the case with $6^{\text {th }}$ most online activity. Initially this mephedronelinked death received only one Google News return, from his local newspaper (Brighton Argus, 13/02/10, Walker, 2010). This was despite this fatality occurring in the Brighton area (Hove is adjacent to Worthing, part of the city of 'Brighton \& Hove'). The 'Hove death' was not reported online again until the day that the 'Scunthorpe 2' story broke (17/03/10), now as the first fatality where mephedrone was toxicologically confirmed. 
"A 46-year-old Marks \& Spencer worker has become the fifth person in Britain to die after taking the drug known as miaow-miaow... The results of post-mortem toxicology tests have blamed mephedrone poisoning for the cardiac arrest." (The Times, 17/03/10, Nugent 2010)

Although the press could now present the 'Hove death' as proving (in The Mirror's Tony Parson's words) that "Our children need protection from mephedrone", alternative sources of information concerning this fatality were already available online. The following extract is taken from the Internet discussion forum Drugs Forum.

"I'm not going to go into length about this man dying in Hove, but a few facts that the newspapers have not reported should be know, obviously i can only state things in a certain way on here, I personally knew this person, although was not present on this day, or involved in any activities ,but it is a sad event for me, although the newspapers and police and stated that mephedrone was found, there were other substances taken, the most likely method of use of mephedrone was intravenously... whatever links they say, it is only a small factor in what happened although will be used to try and make it illegal. i hope they find it had not connection, as whatever happened that night, he was a lovely guy and i would hate him to be remembered for this." [posted by Stilzer, 1103-2010, 17:13]

http://www.drugs-forum.com/forum/showthread.php?t=118360 (accessed March 2010)

This interactive use of the internet by "Stilzer", during the time period between the local newspaper article and the confirmation that mephedrone was involved, demonstrates a degree of foresight about how the case developed. Reports from a subsequent inquest, though only returned by Google News for two local newspapers at the time, revealed that mephedrone use was indeed intravenous and that there were other factors underlying this fatality.

\section{"Mephedrone death man had injected four doses, inquest hears}

A middle-aged man from East Sussex died after being injected with four doses of the former "legal high" drug mephedrone resulting in the second highest ever concentration of the substance experts had ever recorded, an inquest heard. But pathologist Dr David Wright, who conducted a post-mortem examination on John Sterling Smith, said it was "unlikely" that this alone killed him as he was also suffering from severe coronary artery disease. The 46-year-old suffered a cardiac arrest at his home in The Drive, 
Hove, in the early hours of February 7. An inquest at Brighton County Court heard that Mr Smith, a part-time sales assistant, was also HIV positive, suffered from chronic renal disease and high blood pressure, and was an insulin-dependent diabetic. The hearing was told he had spent the evening at his home with two men, having sex and injecting themselves and each other with mephedrone... Detective Sergeant Steve French of Sussex Police told the inquest that he... noticed the presence of drug paraphernalia including needles and syringes plus unidentified tablets and powder." (Brighton Argus, 27/05/10 ${ }^{8}$ )

The above details, of intravenous-use by a middle-aged gay man with fatal underlying health problems, hardly fit the rules of relevance for a newsworthy drug death, but the toxicologically confirmed 'Hove death' could be linked to more speculative but stereotypical cases, such as alleged first teenage experiment. One such newsworthy case involved a teenage Buckinghamshire college student in Berkhamstead, Hertfordshire (Table 1, \#11), reportedly the second mephedrone fatality after the 'Brighton death'.

\section{TEENAGER DIES 'AFTER EXPERIMENTING WITH LEGAL DRUG MEOW MEOW'}

"A teenager died at a house party after experimenting for the first time with a dangerous drug available legally on the internet, friends said yesterday. The body of Ben Walters, 18, was found in the same flat as a 28-year-old woman who is now fighting for her life in hospital. Both are understood to have taken mephedrone which is sold as a fertiliser but produces a similar euphoric high to ecstasy..." (The Daily Mail, 21/01/10, updated 10/02/10, Levy, 2010)

In a similar fashion to the 'Hove death', the 'Berkhamstead death' was discussed in the same online forum by persons critical of the traditional news media, and purporting insider knowledge of what really happened.

"Ben was a good friend of mine. I can't fucking believe this has happened. This article is full of bullshit though. 1) It was not Ben's first time on mephedrone, he had done it before, along with other drugs. 2) I've know he had got hold of some morphine pills and apparently he took them at the party, and that's what he overdosed on - not drone. 3) He doesn't own the flat like it says in the article?"

(posted by Captain, 23-01-2010, 09:07) 
"The article is really full of shit. Ben had a good history of drug use. This wasn't his first time on mephedrone and he was sold some morphine pills as posted in the comments. My condolensces go out to the family. However I feel I may take the liberty in speking to the daily mail about how the twist on the story and the misinformation aswell as the complete disrespect to bens life..."

(posted by Snakey, 26-01-2010, 02:31)

http://www.drugs-forum.com/forum/showthread.php?t=115536 (accessed March 2010)

Those contributing to the 'thread' above show a degree of insight into the circumstances of this fatality, as corroborated by reports from a subsequent inquest (e.g. morphine use, ownership of the flat). The quotes below contrast online coverage of this inquest's findings between the UK's largest selling newspaper and one local one to the college the deceased had attended. The national title focuses on the case's links to mephedrone, while the local newspaper's report (retrieved by Google News as a "related article") did not mention this drug at all, but as with the Brighton Argus coverage of the 'Hove death' or the Scunthorpe Telegraph (2011b) coverage of the 'Scunthorpe 2', provided more details of actual causes (and drug use involved).

\section{"Meow pair killed at druggie 18th birthday}

Drama student Ben Walters, 18, still had mephedrone in his body when he snorted lines of morphine. Trainee driving instructor Lindsey Wilson, 28, took morphine and horse tranquiliser ketamine. Both overdosed at a friend's 18th birthday bash at a flat in Berkhamsted, Herts, belonging to Lindsey's cousin Sarah Downing. [...] Sarah told the inquest at Hatfield, Herts: "We had all taken drugs before, but never morphine. [...] She said none of the group took meow meow that night but had done so on previous nights. Some of the morphine was taken as tablets, but capsules were also broken open and the contents snorted off a table. Coroner Edward Thomas said Ben died of drug intoxication, and Lindsey of a brain injury due to a mixed drug overdose. Verdicts: Misadventure. Mephedrone was made illegal in April after a spate of deaths." (The Sun, 20/10/10, Haywood, 2010b)

\section{"Parents of Amersham and Wycombe College student Ben Walters say he was "let down" by friends after morphine overdose}

... A coroner warned youngsters about the dangers of taking drugs at the end of a joint inquest into the deaths of 18-year-old Ben, of Swallowtail Walk, Berkhamsted, and 28year-old Lindsey Wilson - who died a week later in hospital after also taking morphine at the same time. The Hatfield inquest heard they were among a group of five who took the drug on January 18. All except Miss Wilson, a trainee driving instructor, were 
students at Amersham and Wycombe College. Three of the youngsters who took the drug were sick afterwards - but Miss Wilson and Mr Walters took more after snorting morphine from broken capsules after suffering no side effects." (Buckinghamshire Free Press, 19/10/10, Carsewell, 2010)

This was not the only difference noted between local newspapers and other online press. It was noteworthy that some local reporters began to question the merits of 'raising awareness' about mephedrone, particularly if during their campaigns, deaths or other harms attributed to the drug started to affect local people (Plymouth Herald, 31/03/10; Newcastle Evening Chronicle, 26/04/10, Warburton, 2010).

\section{TEENAGERS 'IGNORING’ MEPHEDRONE WARNINGS}

"York GP Dr David Fair said he had seen more cases of people who had taken mephedrone recreationally since The Press began its campaign." (York The Press, 11/03/10, Harris R., 2010)

\section{"Drug death woman was mephedrone user, say police}

“...DCI Costello also backed The Press's Menace of Mephedrone campaign, which aims to outlaw the drug. He said: "I think The Press has done the right thing in making people aware of this substance." (York The Press, 23/03/10, Bell, 2010)

\section{Implications}

Do media false-alarms lead to real harms?

It has long been contended that the media's drugs reporting is iatrogenic news, with scare stories not only publicising a new drug but also increasing the likelihood that users will experience bad reactions to it (Bunce 1979), creating "a vicious circle of increasing validation" (Becker, 1967 p167). The Google data presented here would support the hypothesis that reports of deaths caused by a drug increases interest in buying that drug. On Figure 6 for example, it is noteworthy that press coverage was greatest at the time of the ban (arguably indicating that the news media are more interested in publicising their influence on legislation), while searches for "mephedrone" had twin peaks, the lesser of which coincided with the ban, the greater at the time of the 'Scunthorpe 2' deaths (arguably demonstrating the drug-interested public are 
motivated by scare stories). Indeed, at that time according to Google "mephedrone" briefly became the UK's most searched for drug on the Internet (Ncube, 2010). This might be viewed as the 'download generation' downloading drugs.

Figure's 1-6 suggest a 'boomerang effect'. That is more news of drug deaths causes more interest in drug buying. That ads for mephedrone could appear alongside stories of a harm attributed to the drug may have influenced this linkage (Power, 2010), formulating a mixed message mirroring alcohol ads in newspapers. Of course this does not mean that all of those entering the search term "mephedrone buy" were intent on doing so, let alone became a user because of concurrent media coverage. Nor do Google Trends reveal the precise numbers who searched for mephedrone in this way, let alone why. Nevertheless, should any online readers have wished to have purchase mephedrone after reading a press story about it, there was a unique opportunity to do so here. Not only could the news source state where the drug might be sourced, this was effectively the same source - the Internet.

Another potential danger, related to the boomerang effect' and inherent to drug scares, is 'cry wolf-ism'. That is when de-bunked false-alarms about a new drug make users less willing to believe subsequent messages concerning real harm caused by that drug (Murji, 1998) and crucially any possible risk from the next new drug of concern. Six toxicologically confirmed drug-related deaths involving mephedrone were recorded in England \& Wales during 2010 (out of a total of 2,747 drug-related deaths) and in two of these cases mephedrone was the only drug recorded/detected (ONS, 2011). Similarly 'elephant-in-the-room effect', that is where the real dangers of an existing drug are ignored because the media focus on a novel but less harmful one. For example, it was reported that the mephedrone scare detracted from very real public health concerns about alcohol (Laurance, 2010a), while the drinks/licensed trade industry were 
keen to associate themselves with anti-mephedrone campaigns at the time (Ely, 2010). It was also claimed that there was evidence that during the mephedrone scare harms from already illegal drugs fell (Bird, 2010; Nutt, 2011). Following the ban, users reportedly returned to these (Laurance, 2010b) and/or turned to new more harmful/unknown 'legal highs' (Durham, 2011 online; Measham, 2011), although the deaths involving these substances have received less media attention (e.g. Ivory Wave, 5Me0-DALT or phenazepam). Although the ban may have eliminated UK-based online vendors, it did not eliminate mephedrone use (McElrath \& O’Neill, 2011; Measham et al, 2011), it may have increased harm (Winstock et al, 2010), and deaths continue to occur but receive little media attention other than in local press (e.g. Halesowen News, 13/07/11).

False-alarms about mephedrone are also likely to impact on harms felt by users of other drugs. One of the 18 most newsworthy deaths (Table $1 \# 4$ ), reported on the day after the ban (19/04/10), happened in Cumbria, England's most rural county. Despite proving to be another false-alarm, the local police made mephedrone a priority, one which was to have repercussions in a ten-fold increase in drug arrests (i.e. of cannabis users) at the local summer 2010 music festival (Power, 2011).

"With Kendal Calling... There was a big issue at that time about people dying from legal highs. So for us it was a health protection issue rather than anything else. We had problems with mephedrone" (Mark Pennone of Cumbria Police quoted in Power, 2011)

The impact of media reports on those close to the deceased also needs consideration. The reporting of newsworthy drug deaths might viewed as 'journalistic ghoul-ism', that is where (drug) news is manufactured by taking interest in stories involving death. Who benefits from publicising tragedies? The most newsworthy mephedrone scare deaths were similar to the high profile ecstasy deaths of the 1990s, focusing on alleged teenage experimenters (Forsyth 2001b; 
Manning, 2006). Subsequent inquests found that these highest profile fatalities were not caused by mephedrone (see Table 1), and although others did involve the drug, it was not always a causal factor. In other cases mephedrone was a factor, sometimes involving underlying health problems and often involving other less newsworthy drugs by older experienced users (Dargan \& Wood, 2011, pp82-84). From Table 1 and Figures 1-6, it can be seen that media interest was greater in alleged harms not caused by the drug before the ban, than in toxicologically confirmed cases after the ban.

In Lord Mandelson's words (BBC News, 2010b, above) "following the news" of the 'Scunthorpe 2' false-alarm which made him aware of mephedrone, incumbent PM Gordon Brown referred to the Advisory Council for the Misuse of Drugs and the drug was banned (enforced 16/04/10), amid resignations of ACMD members who felt the drug had been banned "very speedily" (within one month) but not "very carefully" to find favour with newspaper editors (Fleming, 2010; Kmietowicz, 2010; Morris, 2010; Sare, 2010) - arguably another falsealarm induced harm. Brown's own stance echoed that of Sir Edward Henry, who as Metropolitan Police Commissioner nearly 100 years earlier had responded similarly to unsubstantiated media claims about the 'drug de jour' (cocaine) resulting in emergency prohibition in advance of research evidence (Kohn, 1992; Spear, 2002).

"... subject to their $[\mathrm{ACMD}]$ advice we will take immediate action. We are determined to act to prevent this evil [mephedrone] hurting the young people of our country." (UK PM Gordon Brown, quoted by Reuters, 24/03/10, Castle \& Addison, 2010)

"[there is a need]... to stamp out the evil [cocaine] now rapidly assuming huge dimensions, special legislation is imperatively needed" (Sir Edward Henry 1916, quoted in Spear 2002 p4.)

Those responsible for mephedrone's prohibition denied that the media's coverage of the 'Scunthorpe 2' had any bearing on their decision, for example the Home Secretary who 
oversaw the ban, quoted below, in Scunthorpe's local newspaper, five days after he resigned his shadow cabinet post.

"FORMER home secretary Alan Johnson stands by the decision to ban mephedrone, claiming it was "unconnected" to the deaths of two North Lincolnshire teenagers... Mr Johnson said: "The decision to ban mephedrone (M-CAT) was unconnected to these tragic deaths. It was the result of a comprehensive study by the Advisory Council On The Misuse Of Drugs. The unanimous recommendation to ban the drug made by the scientists, clinicians and other experts on the Advisory Council On The Misuse Of Drugs to prevent tragedies in the future was based on painstaking evidence."' (Scunthorpe Telegraph, 26/01/11, 2011c)

Regardless of the accuracy of this quote (e.g. local press impartiality regarding unanimity) it begs the question of what "painstaking evidence" the ACMD conducted, given that the findings of inquests into the alleged mephedrone deaths were unavailable at the time of the ban. In their report on consideration of the cathinones it was interesting to note the that (chemistry aside) the ACMD had used evidence from the Internet, including "visits to the FRANK website relating to the cathinones page" (a government anti-drug site) and Google Insights "to determine the proportion of searches, using Google, to search for the word 'mephedrone' since January 2009 to March 2010 in the UK (England region only)" (Home Office, 2010 p14.).

\section{Has the Internet impacted on drug news?}

The ACMD's utilisation of Google evidence was not the only way in which mephedrone's prohibition was shaped by the Internet. The speed with which this process was to run its course in cyberspace contrasts with Cornwell \& Linders (2002) view of drug scares being carefully crafted over time. The lifecycle of the mephedrone scare may have been accelerated by unsubstantiated local stories being amplified across the world's online media (Fleming, 2010).

A hierarchy of detail is suggested, between more measured local media accounts to 
inter/national mephedrone-focussed caricature. Buffering this, the advent of the Internet also meant that more detailed local drug news could be accessed worldwide ('glocal' knowledge). These findings support Belackova et al's (2011) description of 'local news for local people' by local reporters with local knowledge, resulting in less sensationalism of local drug news, in that mephedrone stories published online by local titles were more likely to mention the role of alcohol, pharmaceuticals and social problems in individual cases.

The interactive properties of the web might be viewed as having led to drug news 'democratisation', undermining the credibility in official (drug) information via blogging, Internet forums, social networking and by newspaper readers posting comments at the foot of news stories about mephedrone, including many of the examples cited here (e.g. Brighton Argus, 2010; The Daily Mail, 2010; Ferguson, 2010; Harris, 2010; Parsons, 2010). In contrast to Murji's (1998) observation, this counter-reaction was not restricted to the sections of the liberal press read by academics. Individuals, such as those posting on Drug Forum, were able to contest stock drug scare stories as they were applied to mephedrone among their fellow users/surfers and beyond. This supports McRobbie and Thornton's (1995) long-standing contention that, as the 'mass-media' diversifies, depictions of so-called folk-devils will increasingly be challenged, if those being demonized can access their own 'micro-media'.

At the time of the mephedrone scare, access to dissenting online discourses may have been limited to the "digitally savvy" (Taylor, 2010). That is to young people more likely to use the drug rather than law-makers such as Lord Mandelson. In the year since the mephedrone scare, this 'digital divide' is likely to have reduced as numbers accessing social media increase, furthering the power of interactive media to subvert traditional news sources, as evidenced by events like the 'Arab Spring' or the UK online campaign to dissuade advertisers from The 
News of the World. The question remains whether as more consumers retrieve (drug) news online, the traditional news media will adapt to this change, and inevitably use social media to increase their influence, arguably turning today's freedom into tomorrow's tool of oppression?

The following extracts illustrate how the advent of user-generated content has created new opportunities and challenges for journalists and researchers alike. The first, published in an academic journal, highlights how traditionally researchers found that users learned about a drug via the news media. The second, posted on a social networking site (Facebook), how the media learned about mephedrone from users via the Internet - a virtual journalistic rolereversal.

"I had never heard of it (crack) until then, but when I read it was better than sex and that it was cheaper than cocaine and it was an epidemic, I wondered what I was missing. I questioned why I seemed to be the only one not doing the drug. The next day I asked some friends if they knew where to get some." (US college student interviewed during the 1980s crack scare, Reinarmen \& Levine, 1989 pp14-17)

"Hi, I'm doing a radio feature about Mephedrone for Red Radio in Brighton. I'd really like to hear from anyone who's taken the drug and has had a bad experience or has been addicted to it. I'm happy to keep all sources anonymous, if that's what you'd prefer. Could you get in touch with me on [phone number and e-mail address removed] or send me an email of facebook? Thanks. Natalia" (Facebook: Boycott Mephedrone, 18/02/10, 10.24am)

http://www.facebook.com/twitter/\#!/group.php?v=wall\&ref=search\&gid=15547410968 $\underline{9}$ (accessed February 2010)

Although, the above quote might be viewed as another example of journalistic 'ghoul-ism', this online posting is of interest because rather than traditional interviewing the journalist combines digital media channels (social-networking, e-mail) with traditional communications (telephone and radio) in manufacturing drug news. Research similarly needs to adapt. For example, online news can make more use of visual imagery (photography, video) than newsprint. A secondary 
analysis of the sources used here could have looked at how online portrayals of the deceased in mephedrone cases varied (e.g. between local and national titles). The techniques employed here can be used to plot other drug scares, whether in the future or retrospectively, for example entering the term "salvia divinorum" into Google Trends produces a short-lived web search and online news spike in March 2008, predominantly from US locations. This paper investigated the mephedrone scare by using such Internet tools, and in doing so produced evidence in support of the contention that news reports, especially inaccurate stories of disproportionate harms, precede increased interest in a drug, with all the additional risks that this is likely to entail.

Notes $\quad{ }^{1}$ An example of the 'boomerang effect' in the drug field is where Public Service Announcements about cannabis increased risk of use among vulnerable young people (e.g. Kang et al, 2009).

2 National newspaper titles are prefixed with "The", local titles with the locality's name

${ }^{3}$ All quotes centred in bold are headlines.

4 The News of the World ceased publication on 10/07/11 following a phonehacking and corruption scandal and is no longer available online.

5 The 'wash up' refers to a mechanism of the UK Parliament, which operates during the period when an election is called, to allow some bills to be fasttracked into law, rather than being lost or delayed until after the election.

${ }^{6}$ St Patrick's Day is arguably synonymous with binge drinking in England.

${ }^{7}$ The Daily Mirror was the only national UK newspaper to support PM Gordon Brown's re-election bid. Tony Parsons is a former $N M E$ journalist who selfreported amphetamine use with punk-rockers in the 1970s (Farndale, 2001).

8 This story was later amended online to include the line "It seems unlikely he would have died when he did without mephedrone".

\section{References}

Alderman, G. (2010) What next - penalising students for taking caffeine? The Guardian, May $24^{\text {th }}$. Retrieved July 2011 from http://www.guardian.co.uk/commentisfree/2010/may/24/drugspolicy-transform-symposium

Argus, the (2010) Mephedrone death man had injected four does, inquest hears. The Argus, May $27^{\text {th }}$. Retrieved July 2011 from 
http://www.theargus.co.uk/news/8189807.Mephedrone_death_man_had_injected_four_doses inquest_hears/

BBC News (2010a) Northern Ireland Executive unanimous on mephedrone ban. BBC News Channel, March $26^{\text {th }}$. Retrieved July 2011 from

http://news.bbc.co.uk/1/hi/northern_ireland/8588796.stm

BBC News (2010b) Review pledged over use of legal high drug mephedrone. BBC News Channel, March $17^{\text {th }}$. Retrieved July 2011 from http://news.bbc.co.uk/1/hi/uk/8571935.stm

Bean, P. (1993) Cocaine and Crack: The promotion of an epidemic. In: Bean P, (Ed.). Cocaine and Crack: Supply and use. London: Macmillan; 59-75.

Becker, H.S. (1967) History, Culture and Subjective Experience: An exploration of the social bases of drug-induced experiences. Journal of Health and Social Behavior, 8: September, 163176.

Belackova, V., Strastna, L. \& Miovsky, M. (2011) 'Selling by drugs': Content analysis of the coverage of illicit drugs in different news media types and formats. Drugs, Education, Prevention \& Policy. 18:6, 477-489.

Bell, J. (2010) Drug death woman was mephedrone user say police. The Press, March $23^{\text {rd }}$. Retrieved July 2011 from http://www.yorkpress.co.uk/news/campaigns/mephedrone/5077950.Drug_death_woman_was mephedrone_user_say_police/

Berlins, M. (2006) Charles Clarke shouldn't fret about the legal chaos over cannabis. It's not even on his boss's respect agenda. Guardian, January, $18^{\text {th }}$.

Bird, S. (2010) How Lethal is mephedrone. Straight Statistics, April 15 ${ }^{\text {th }}$. Retrieved July 2011 from

http://www.straightstatistics.org/article/how-lethal-mephedrone-dealing-registration-delays

Braden, W. (1973) LSD and the press. In Cohen, S. \& Young, J. (Eds) The Manufacture of News: Social problems deviance and the mass media. Beverly Hills: Sage.

Breyer, B.N. \& Eisenberg, M.L. (2010) Use of Google in Study of Noninfectious Medical Conditions. Epidemiology, 21:4, 584-585.

Breyer, B.N., Sen, S., Aaronson, D.S., Stoller, M.L., Erickson, B. A. \& Eisenberg, M. L. (2011) Use of Google Insights for Search to Track Seasonal and Geographic Kidney Stone Incidence in the United States. Urology, 78:2, 267-271.

Britten, N. \& Whitehead, T. (2010) Police investigate deaths of two teens linked to mephedrone. The Telegraph, March, $16^{\text {th }}$. Retrieved July 2011 from http://www.telegraph.co.uk/news/uknews/7458101/Police-investigate-deaths-of-two-teenslinked-to-mephedrone.html 
Brooker, C. (2010) THE MOST DANGEROUS DRUG ISN'T MEOW MEOW. IT ISN'T EVEN ALCOHOL ... Newspapers Are the Biggest Threat to the Nation's Mental Wellbeing. The Guardian, March $22^{\text {nd }}$. Retrieved July 2011 from http://www.guardian.co.uk/commentisfree/2010/mar/22/charlie-brooker-newspapersdangerous-drug

Bunce, R. (1979) Social and Political Sources of Drug Effects: The case of bad trips on psychedelics. Journal of Drug Issues, Spring, 213-233.

Butler, A. (2010) MEOW MEOW BANNED. Daily Mirror, March $28^{\text {th }}$. Retrieved July 2011 from

http://www.mirror.co.uk/news/top-stories/2010/03/28/meow-meow-banned-115875-22143710/

Carneiro, H.A. \& Mylonakis, E. (2009) Google Trends: A Web-Based Tool for Real-Time Surveillance of Disease Outbreaks. Clinical Infectious Diseases, 49:10, 1557-1564.

Carsewell, A. (2010) Parents of Amersham and Wycombe College student Ben Walters say he was "let down" by friends after morphine overdose. Buckinghamshire Free Press, October $12^{\text {th }}$. Retrieved July 2011 from

http://www.bucksfreepress.co.uk/news/localnews/highwycombe/8461880.Student_let_down by_friends_after_drug_death/

Castle, T. \& Addison, S. (2010) Brown pledges to act on mephedrone. Reuters, March $24^{\text {th }}$. Retrieved July 2011 from http://uk.reuters.com/article/2010/03/24/uk-britain-mephedroneidUKTRE62N39J20100324

Choi, H. \& Varian, H. (2009) Predicting the present with Google Trends. Google Inc. Online report. Retrieved July 2011 from

http://static.googleusercontent.com/external_content/untrusted_dlcp/www.google.com/en//goo gleblogs/pdfs/google_predicting_the_present.pdf

Cohen, S. (1972) Folk Devils and Moral Panics: The creation of the mods and rockers. London: McGibbon \& Kee.

Collin, M. with Godfrey, J. (1997) Altered state: The Story of Ecstasy Culture and Acid House. London: Serpent's Tail.

Cornwell, B. \& Linders, A. (2002) The Myth of the "Moral Panics": An alternative account of LSD prohibition. Deviant Behavior, 23: 4, 307-330.

Daily Mail, the (2010) Anti-drugs Labour MP's son sells 'legal high' meow meow from his drug accessory shops. Daily Mail, March $26^{\text {th }}$. Retrieved July 2011 from http://www.dailymail.co.uk/news/article-1260818/Anti-drugs-Labour-MPs-son-sells-meowmeow-drug-accessory-shops.html\#ixzz1Rt3AkNVD

Dargan, P. \& Wood, D. (2011) 'Technical report on mephedrone.' Chapter 3 In. Sedefov, R. \& Gallegos, M. (Eds.) Report on the risk assessment of mephedrone in the framework of the Council Decision on new psychoactive substances. Lisbon: ECMDDA; 49-100. 
Davey, Z., Corazza, O., Schifano, F. \& Deluca, P. (2010) Mass-information: Mephedrone, myths, and the new generation of legal highs. Drugs \& Alcohol Today, 10:3, 24-28.

Davies, J.B. \& Ditton, J. (1990) The 1990s: Decade of the Stimulants. British Journal of Addiction, 85:6, 811-813.

Dillon, P., Goldspink-Lord, L. \& Parkhill, N. (1996) Sex, Drugs and Just Say No: A Media Perspective. The International Journal of Drug Policy, 7:3, 183-186.

Dixon, B. (2009) Row sparked over drug adviser sacking. Current Biology, 19:22, R1011R1012.

Durham, M. (2011) Ivory Wave: The next mephedrone? Emergency Medicine Journal, 28:1059-1060 doi:10.1136/emj.2011.112920.

Dyer, C. (2009) Scientists want more protection after government adviser is sacked. British Medical Journal, 339: b4563.

Edwards, G. (1989) Blasted with Ennui. British Medical Journal, 289: 136.

Ely, M. (2010) Legal High Drug ban Could be Extended: Mephedrone users to be barred from Aberdeen pubs - and other cities could follow. The Publican, February, $17^{\text {th }}$. Retrieved July $2011 \mathrm{from} \mathrm{http://www.thepublican.com/story.asp?storycode=66414}$

Erikson, A. \& Erikson, A.M. (2010) Cheap killer showing up and NZ parties. New Zealand Herald, March $2^{\text {nd }}$. Retrieved July 2011 from

http://www.nzherald.co.nz/nz/news/article.cfm?c_id=1\&objectid=10629320

Farndale, N. (2001) The Parsons tale. The Telegraph, June $20^{\text {th }}$.

Farrell, M. (1989) Ecstasy and the Oxygen of Publicity. British Journal of Addiction, 84:8, 943.

Ferguson. P. (2010) Legal 'high' costs Hereford man his freedom. Hereford Times, March $25^{\text {th }}$. Retrieved July 2011 from

http://www.herefordtimes.com/news/local/hereford/5081413.Legal_high_costs_Hereford_m an_his_freedom/

Fifield, N. (2010) Woldgate College pupil collapses after taking 'legal high'. The Press, January, $14^{\text {th }}$. Retrieved July 2011 from

http://www.yorkpress.co.uk/news/campaigns/mephedrone/4850421.Woldgate_College_pupil_c ollapses_after_taking legal_high /

Fleming, N. (2010) Miaow-miaow on Trial: Truth or trumped-up charges? New Scientist, March $18^{\text {th }}$ Retrieved July 2011 from 
http://www.newscientist.com/article/dn18712-miaowmiaow-on-trial-truth-or-trumpedupcharges.html

Forsyth, A.J.M. (2001a) A Design for strife: Alcopops - licit drug, familiar scare story. International Journal of Drug Policy, 12:1, 59-80.

Forsyth, A.J.M. (2001b) Distorted?: A quantitative exploration of the reporting drug fatalities in the popular press. International Journal of Drug Policy, 12:5/6, 435-453

Gilliver, D. (2010) The last few months have seen a dramatic increase in use of - and media interest in - 'legal highs', especially mephedrone or 'miaow/meow'. Drink \& Drug News. January 18th. Retrieved July 2011 from http://www.drinkanddrugsnews.com/magazine/ed6a68c4a6ba47b38e575dbf220b5f33.pdf

Goode, E. (2008) Moral Panics and Disproportionality: The case of LSD use in the sixties. Deviant Behavior, 29: 6, 533-543.

Gould, A. (1996) Drug issues and the Swedish press. International Journal of Drug Policy, 7:2, 91-104.

Graham, L., Matthews, S., Dunbar, J.K. \& Stoner, N. (2010) The National Drug Related Death database (Scotland) Report 2009. Edinburgh: Information Services Divisions.

Greatrex, J. (2010) Legal highs delivered straight to your door by Birmingham firm. Sunday Mercury, March $7^{\text {th }}$. Retrieved July 2011 from

http://www.sundaymercury.net/news/midlands-news/2010/03/07/legal-highs-delivered-

straight-to-your-door-by-birmingham-firm-66331-25976764/

Hari, J. (2010) Drug Warriors -- It's Time for You to Go to Rehab. Huffington Post, September $29^{\text {th }}$. Retrieved July 2011 from

http://www.huffingtonpost.com/johann-hari/drug-warriors---its-time_b_743107.html

Harris, E. (2010) Mephedrone found not guilty, but the next legal high may be a killer. The Guardian, August $5^{\text {th }}$. Retrieved July 2011 from

http://www.guardian.co.uk/science/2010/aug/05/mephedrone-not-guilty

Harris, R. (2010) TEENAGERS 'IGNORING' MEPHEDRONE WARNINGS. The Press, March $11^{\text {th }}$. Retrieved July 2011 from http://www.yorkpress.co.uk/news/5053373.Teenagers_ignoring mephedrone_warnings I

Halesowen News (2011) Rowley Regis man died after taking lethal cocktail of drugs. Halesowen News, July $13^{\text {th }}$. Retrieved July 2011 from

http://www.halesowennews.co.uk/news/9137776.Rowley_Regis_man_died_after_taking_lethal _cocktail_of_drugs/

Haywood, L. (2010a) Meow Meow in impotence link. The Sun, April $1^{\text {st }}$. Retrieved July 2011 from 
http://www.thesun.co.uk/scotsol/homepage/news/2917118/Meow-meow-in-impotence$\underline{\text { link.html }}$

Haywood, L. (2010b) Meow pair killed at druggie $18^{\text {th }}$ birthday party. The Sun, October $20^{\text {th }}$. Retrieved July 2011 from http://www.thesun.co.uk/sol/homepage/news/3187808/Teen-and-woman-die-after-takingdrugs-including-meow-meow-inquest-hears.html

Home Office (2010) ACMD report on the consideration of the cathinones. Online report. Posted March 2010. Retrieved July 2011 from http://drugs.homeoffice.gov.uk/publicationsearch/acmd/acmd-cathinodes-report-2010

Hurriyet (2009) Death from the internet sell. Hurriyet, December $23^{\text {rd }}$. Turkish edition. Retrieved July 2011 from http://www.hurriyet.com.tr/dunya/13279717.asp

Jenkins. P. (1999) Synthetic Panics: The symbolic politics of designer drugs. New York: NYU Press.

Jones, S. (2010) Britain Now 'Designer Drugs' Capital of Europe. Epoch Times, March $2^{\text {nd }}$. URL: Retrieved July 2011 from http://www.theepochtimes.com/n2/content/view/30642/

Jones, S.C., Hall, D. \& Cowlin, F. (2008) Newspaper Coverage of Drug Policy: An analysis of pre-election reporting of the Greens' drug policy in Australia. Drug \& Alcohol Review, 27:1, 511.

Kang, Y., Cappella, J.N. \& Fishbein, N. (2009) The Effect of Marijuana Scenes in AntiMarijuana Public Service Announcements on Adolescents' Evaluation of Ad Effectiveness. Health Communication, 24:6, 483-493.

Kmietowicz, Z. (2010) Home secretary bans mephedrone after taking advice from depleted council. British Medical Journal, 340:c1784. doi: 10.1136/bmj.c1784.

Kohn, M. (1992) Dope Girls: The Birth of the British Drug Underground. London: Lawrence \& Wishart.

Kohn, M. (1997) The chemical generation and its ancestors: Dance crazes and drug panics across eight decades. International Journal of Drug Policy, 8:3, 137-142.

Laurance, J. (2010a) Critical alcohol review hidden by mephedrone row. The Independent, April 19 $9^{\text {th }}$. Retrieved July 2011 from http://www.independent.co.uk/news/uk/politics/criticalalcohol-review-hidden-by-mephedrone-row-1948191.html

Laurance, J. (2010b) Mephedrone ban blamed for rise in cocaine deaths. The Independent, November $24^{\text {th }}$. Retrieved July 2011 from http://www.independent.co.uk/life-style/health-andfamilies/health-news/mephedrone-ban-blamed-for-rise-in-cocaine-deaths-2142097.html 
Levine, H.G. \& Reinarman, C. (1988) The politics of America's latest drug scare. In O'Curry, R. (Ed.) Freedom at Risk: Secrecy, Censorship and Repression in the 1980s. Philadelphia: Temple UP; 251-258.

Levy, A. (2010) Teenager dies 'after experimenting with legal drug meow meow'. Daily Mail, January $21^{\text {st }}$. Retrieved July 2011 from http://www.dailymail.co.uk/news/article$\underline{1245078 / \text { Teenager-dies-experimenting-legal-drug-meow-meow.html }}$

Lister, S. (2010) Teenagers' deaths were not caused by "legal high" mephedrone. The Times, May $28^{\text {th }}$. Retrieved July 2011 from http://www.timesonline.co.uk/tol/news/uk/article7139387.ece

Loughborough Communications Research Centre (2010) Representations of Drug Use and Drug Users in the British Press: A content analysis of newspaper overage. London: UK Drug Policy Commission.

Manning, P. (2006) There's no Glamour in Glue: News and the symbolic framing of substance use. Crime, Media, Culture. 2:1, 49-66.

McElrath, K. \& O'Neill, C. (2011) Experiences with mephedrone pre and post-legislative controls: Perceptions of safety and sources of supply, International Journal of Drug Policy, 22:2, 120-127.

McRobbie, A. \& Thornton, S.L. (1995) Rethinking 'moral panic' for multi-mediated social worlds. British Journal of Sociology, 46:4, 559-574.

Measham, F., Moore, K., Newcombe, R. \& Welch, Z. (2010) Tweaking, Bombing, Dabbing and Stockpiling: The emergence of mephedrone and the perversity of prohibition. Drugs and Alcohol Today, 10:1, 14-21.

Measham, F., Wood, D.M., Dargan, P.I. \& Moore, K. (2011) The Rise in Legal Highs: Prevalence and patterns in the use of illegal drugs and first- and second-generation "legal highs" in South London gay dance clubs. Journal of Substance Use, 16:4, 263-272

Metro, the (2009) Pupils face ban for killer net drug meow meow". The Metro, December $4^{\text {th }}$. Retrieved July 2011 from http://www.metro.co.uk/news/802973-pupils-face-ban-for-killer-net$\underline{\text { drug }}$

Metro, the (2010) Mephedrone 'not to blame for deaths of Scunthorpe teenagers' The Metro, May $18^{\text {th }}$. Retrieved July 2011 from http://www.metro.co.uk/news/828366-mephedrone-not-toblame-for-deaths-of-scunthorpe-teenagers\#ixzz1Q68CCuOB

Millard, N. (2010) Meow meow ban within weeks. The Sun, March $29^{\text {th }}$. Retrieved July 2011 from http://www.thesun.co.uk/sol/homepage/news/2911173/Meow-meow-ban-hold-up-afterdrugs-tsar-quits.html

Mitchelstein, E. \& Bockzkowski, P.J. (2009) Between Tradition and Change: A review of recent research on online news production. Journalism, 10:5, 562-586. 
Morris, K. (2010) UK places generic ban on mephedrone drug family. The Lancet, 375:9723, 1333-1334.

Murji, K. (1998) The Agony and the Ecstasy: Drugs Media and Mortality. In Coomber, R. (Ed.), The Control of Drugs: Reason or reaction. Amsterdam: Harwood; 69-85.

Ncube, M. (2010) Tracking Search Habits: The-Mephedrone Ban. Search Engine Watch, May $18^{\text {th }}$. Retrieved July 2011 from http://searchenginewatch.com/3640366

Newcombe, R. (1988) Ecstasy: New drug familiar panic. Mersey Drug Journal, 2:4, 12-14.

Newcombe, R. (2009) Mephedrone: Use of mephedrone (M-cat, Meow) in Middlesbrough. Manchester: Lifeline Publications.

News of the World, the (2010a) Ex-addict calls for ban on mephedrone, or Meow Meow. News of the World, February $6^{\text {th }}$. Retrieved $7^{\text {th }}$ February 2010 from http/l www.newsoftheworld.co.uk/.../news/.../Ex-addict-calls-for-ban-on-Mephedrone-or-MeowMeow-NOW.html [withdrawn $40^{\text {th }}$ July 2011]

News of the World, the (2010b) Dr Hillary. News of the World, February $6^{\text {th }}$. Retrieved $7^{\text {th }}$ February 2010 http://www.newsoftheworld.co.uk/ [withdrawn ${ }^{4}$ July $10^{\text {th }} 2011$ ]

News of the World, the (2010c) IT WAS only a matter of time before the body count started. News of the World, March 21 ${ }^{\text {st }}$. Retrieved 22 $2^{\text {nd }}$ March 2010 from http://www.newsoftheworld.co.uk/ [withdrawn ${ }^{4}$ July $10^{\text {th }} 2011$ ]

Nichols, J. (2011) UK News Reporting of Alcohol: An analysis of television and newspaper coverage. Drug Education, Prevention \& Policy, 18:3, 200-206.

Nugent, H. (2010) John Smith is fifth person to die after taking 'miaow-miaow'. The Times, March $17^{\text {th }}$. Retrieved July 2011 from http://www.timesonline.co.uk/tol/news/uk/crime/article7066159.ece

Nutt, D. (2011) Perverse Effects of the Precautionary Principle: How banning mephedrone has unexpected implications for pharmaceutical discovery. Therapeutic Advances in Psychopharmacology, 1:2, 35-36.

ONS (2011) Deaths related to drug poisoning in England and Wales, 2010. Newport: Office for National Statistics. Data Tables from

http://www.ons.gov.uk/ons/publications/re-reference-tables.html?edition=tcm\%3A77-223960

Parsons, B. (2009) Worthing drug-scare teen died of natural causes. The Argus, December $16^{\text {th }}$. Retrieved July 2011 from

http://www.theargus.co.uk/news/4796771.Worthing_drug_scare_teen_died_of_natural_causes/

Parsons, T. (2010) Why is mephedrone still legal? Our children need protection from it. And themselves. Daily Mirror, March 20 ${ }^{\text {th }}$. Retrieved July 2011 from 
http://www.mirror.co.uk/news/top-stories/2010/03/20/why-is-mephedrone-still-legal-ourchildren-need-protection-from-it-and-themselves-115875-22124583/

Payne, W. (2010) Deadly drug Mephedrone is sold to teenagers on Facebook. Daily Mirror, March $7^{\text {th }}$. Retrieved July 2011 from http://www.mirror.co.uk/news/topstories/2010/03/07/deadly-drug-is-sold-to-teens-on-facebook-115875-22091197/

Plymouth Herald (2010) Two people a day visit Plymouth casualty after taking mephedrone. Plymouth Herald, March 31 ${ }^{\text {st }}$. Retrieved July 2011 from http://www.thisisplymouth.co.uk/Eseeing-rise-mephedrone-use/story-11462701-detail/story.html

Power, M. (2009) Mephedrone: The future of drug dealing? Druglink, March/April, 6-7 \& 9.

Power, M. (2010) World Wired Web Druglink, January/February, 11-13.

Power, M. (2011) Local Laws for Local People Mixmag, 242, 74-75.

Power, M. \& Parry, S. (2010) The Chinese laboratories where scientists are already at work on the new 'meow meow'. Daily Mail, October $4^{\text {th }}$. Retrieved July 2011 from http://www.dailymail.co.uk/home/moslive/article-1267582/The-Chinese-laboratoriesscientists-work-new-meow-meow.html

Rech, J. (2007) Discovering Trends in Software Engineering with Google Trend. Software Engineering Notes, 32. doi: 10.1145/1234741.1234765.

Reid, M. (2010) No law will stop people wanting to get high: Selling small amounts of drugs in clubs is not shocking. It's a responsible idea. The Times, April $1^{\text {st }}$. Retrieved July 2011 from http://www.timesonline.co.uk/tol/comment/columnists/melanie_reid/article7083395.ece

Reinarmann, C. (1997) The Social Construction of Drug Scares In Alder P. A \& Alder P. Constructions of Deviance: Social power, context, and interaction. Belmont CA: Wadsworth; 92-104.

Reinarmann, C. \& Duskin, C. (1992) Dominant ideology and drugs in the media. International Journal of Drug Policy, 2:1, 6-15.

Reinarmann, C. \& Levine, H.G. (1989) Understanding drug scares and building better drug policies. Mersey Drugs Journal, 2:6, 14-17.

Riesch, H. (2010) Changing News: Re-adjusting science studies to online newspapers. Public Understanding of Science, 20:6, 751-770.

Saner, E. (2009) Mephedrone and the problem with 'legal highs': The key side-effect of the mephedrone scare has been a spike in sales - and a government policy now close to breaking point. Guardian, December $5^{\text {th }}$. Retrieved July 2011 from

http://www.guardian.co.uk/society/2009/dec/05/mephedrone-problem-legal-highs 
Sare, J. (2011) How the Media Helped Ban Mephedrone: Misinformation in the media helped politicians push for the criminalisation of the "legal high" mephedrone last year despite a lack of evidence of harm. British Medical Journal, 342, 472-473.

Schofield, K. (2010) Harman snub for meow meow ban. The Sun, March $19^{\text {th }}$. Retrieved July 2011 from http://www.thesun.co.uk/sol/homepage/news/2898812/Harriet-Harman-snub-formeow-meow-ban.html

Scunthorpe Telegraph (2011a) Accidental death verdict in second inquest. Scunthorpe Telegraph, January $25^{\text {th }}$. Retrieved July 2011 from http://www.thisisscunthorpe.co.uk/Accidental-death-verdict-second-inquest/story-11181634detail/story.html

Scunthorpe Telegraph (2011b) Call for review into dispensing of methadone following teen death inquests. Scunthorpe Telegraph, January $26^{\text {th. }}$ Retrieved July 2011 from http://www.thisisscunthorpe.co.uk/drug-swilling/story-11171934-detail/story.html

Scunthorpe Telegraph (2011c) Decision to outlaw mephedrone drug not connected to teen deaths. Scunthorpe Telegraph, January $27^{\text {th }}$. Retrieved July 2011 from http://www.thisisscunthorpe.co.uk/Decision-outlaw-drug-connected-deaths/story-11171980detail/story.html

Seifter, A., Schwarzwalder, A., Geis, K. \& Aucott, J. (2010) The utility of "Google Trends" for epidemiological research: Lyme disease as an example. Geospatial Health, 4:2, 135-137.

Silverman, J. (2010) Addicted to getting drugs wrong. British Journalism Review, 21:4, 31-36.

Sun, the (2009) DEAD TEEN 'TOOK PARTY DRUG' The Sun, November $24^{\text {th }}$.

Taylor. G. (2010) UK Drug Ruling Shows Up Another 'Digital Divide'. Internet Evolution, June $5^{\text {th }}$. Retrieved July 2011 from

http://www.internetevolution.com/author.asp?section_id=920\&doc_id=191493

Taylor, S. (2008) Outside the Outsiders: Media representations of drug use. Probation Journal: The Journal of Community and Criminal Justice, 55:4, 369-387.

Telegraph, the (2010) Mephedrone: Government adviser Dr Polly Taylor quits as drugs row escalates. The Telegraph, March $29^{\text {th }}$. Retrieved July 2011 from

http://www.telegraph.co.uk/health/healthnews/7533742/Mephedrone-government-adviser-Dr-

Polly-Taylor-quits-as-drugs-row-escalates.html

Times of Malta (2010) Drugs adviser quits over 'rushed' mephedrone ban. Times of Malta, March $3^{\text {rd }}$. Retrieved July 2011 from

http://www.timesofmalta.com/articles/view/20100403/world-news/drugs-adviser-quits-overrushed-mephedrone-ban.301011

Townsend, M. (2010) Meow meow was innocent, but the damage has been done. The Observer, June $6^{\text {th }}$. Retrieved July 2011 from 
http://www.guardian.co.uk/society/2010/jun/06/louis-wainwright-nicholas-smith-mephedrone$\underline{\operatorname{nrg} 1}$

Van Hout, M.C. \& Brennan, R. (2010) Plant food for thought: A qualitative study of mephedrone use in Ireland. Drugs, Education, Prevention \& Policy, 18:5, 371-381.

Walker, E. (2010) Hove man's death linked to legal high meow. The Argus, February $13^{\text {th }}$. Retrieved July 2011 from http://www.theargus.co.uk/news/5006052.Hove_man_s_death_linked_to_legal_high_meow/

Warburton, D. (2010) Tributes pour in for victim Josylne Cockburn. Evening Chronicle, March $26^{\text {th }}$. Retrieved July 2011 from

http://www.chroniclelive.co.uk/north-east-news/evening-chronicle-news/2010/03/26/tributespour-in-for-victim-joslyne-cockburn-72703-26115450/

Western Morning News (2010) Fears over 'poor man's cocaine' WMN, February $1^{\text {st }}$. Retrieved July 2011 from http://www.thisisplymouth.co.uk/LEGAL-DRUGS-TEENAGERS-RISK/story$\underline{11385769-\text { detail/story.html }}$

Wilson, G. (2010) Meow is banned from midnight. The Sun, April $16^{\text {th }}$. Retrieved July 2011 from http://www.thesun.co.uk/sol/homepage/news/2934853/Meow-meow-drug-banned-frommidnight.html

Winstock A., Mitcheson, L. \& Marsden J. (2010) Mephedrone: Still available and twice the price. The Lancet, 376:9752, 1537.

Wolfson, S. (2010) Mephedrone - How Dangerous Is The UK's New Favourite Drug. New Musical Express, February $8^{\text {th }}$. Retrieved July 2011 from http://www.nme.com/blog/index.php?blog=10\&title=mephedrone\&more $=1 \& \mathrm{c}=1 \& \mathrm{tb}=1 \& \mathrm{pb}=1$

Wong, L.S. \& Alexander, B.K. (1991) "Cocaine related" Deaths: Media coverage in the War on Drugs. Journal of Drug Issues, 21:1, 105-119.

Worthing Herald (2009) Worthing girl Gabi Price - Mum speaks out against false drug claims. Worthing Herald, December $22^{\text {nd }}$. Retrieved July 2011 from

http://www.worthingherald.co.uk/news/local/worthing_girl_gabi_price_mum_speaks_out_agai nst_false_drug_claims_1_247322

Young J. (1973) The Myth of the drug-taker in the mass media. In Cohen S. \& Young J, (Eds.) The Manufacture of News: Social Problems deviance and the mass media. Beverly Hills: Sage; 326-334. 
Table 1: Most Google News-worthy mephedrone-linked deaths

\begin{tabular}{|c|c|c|c|c|c|c|}
\hline Case & $\begin{array}{l}\text { Estimated } \\
\text { Google } \\
\text { retrievals } \\
\end{array}$ & $\begin{array}{l}\text { Date } 1^{\text {st }} \\
\text { named } \\
\text { online }\end{array}$ & Location & $\begin{array}{l}\text { Age/ } \\
\text { Sex }\end{array}$ & $\begin{array}{l}\text { Other drug use } \\
\text { (unconfirmed } \\
\text { press allegation) }\end{array}$ & $\begin{array}{l}\text { Other causes } \\
\text { (unconfirmed press } \\
\text { allegation) }\end{array}$ \\
\hline$\# 1$ & 9,060 & $16 / 03 / 10$ & Scunthorpe & $18 / \mathrm{M}$ & $\begin{array}{l}\text { alcohol, } \\
\text { methadone \$ }\end{array}$ & - \\
\hline$\# 2$ & 8,730 & $16 / 03 / 10$ & Scunthorpe & 19/M & $\begin{array}{l}\text { alcohol, } \\
\text { methadone \$ }\end{array}$ & - \\
\hline \#3 & 2,490 & $24 / 11 / 09$ & Brighton \& Hove & $14 / \mathrm{F}$ & (ketamine) & $\begin{array}{l}\text { streptococcal A } \\
\text { infection }\end{array}$ \\
\hline$\# 4$ & 2,040 & $19 / 04 / 10$ & Cumbria & $17 / \mathrm{F}$ & $-\$$ & - \\
\hline$\# 5$ & 1,860 & $23 / 03 / 10$ & Yorkshire & $24 / \mathrm{F}$ & $\begin{array}{l}\text { antidepressants } \\
* *\end{array}$ & heart condition \\
\hline \#6 & 1,850 & $13 / 02 / 10$ & Brighton \& Hove & $46 / \mathrm{M}$ & $\begin{array}{l}\text { intravenous use } \\
* *\end{array}$ & $\begin{array}{l}\text { heart condition, } \\
\text { HIV, diabetes, } \\
\text { kidney disease, } \\
\text { high blood pressure }\end{array}$ \\
\hline$\# 7$ & 1,710 & $30 / 09 / 10$ & Teeside & $29 / \mathrm{M}$ & alcohol * & - \\
\hline$\# 8$ & 662 & $19 / 03 / 10$ & Ayr (Scotland) & 19/M & $-* *$ & - \\
\hline$\# 9$ & 634 & $13 / 10 / 10$ & Lancashire & $19 / \mathrm{F}$ & $\begin{array}{l}\text { amphetamine, } \\
\text { BZP, TFMPP } * *\end{array}$ & - \\
\hline$\# 10$ & 492 & $20 / 08 / 10$ & Leicester & $20 / \mathrm{F}$ & $\begin{array}{l}\text { alcohol } \\
\text { ("spiked") ** }\end{array}$ & - \\
\hline$\# 11$ & 457 & $21 / 01 / 10$ & Berkhamstead & $18 / \mathrm{M}$ & morphine $*$ & - \\
\hline$\# 12$ & 378 & $18 / 02 / 10$ & Wigan & $20 / \mathrm{F}$ & amphetamine $* *$ & - \\
\hline$\# 13$ & 310 & $16 / 04 / 10$ & Kensington & $28 / \mathrm{F}$ & $\begin{array}{l}\text { alcohol, GHB, } \\
\text { diazepam ** }\end{array}$ & - \\
\hline$\# 14$ & 303 & $26 / 04 / 10$ & Newcastle & $18 / \mathrm{F}$ & $\begin{array}{l}\text { alcohol, } \\
\text { methadone \$ }\end{array}$ & - \\
\hline$\# 15$ & 243 & $19 / 10 / 10$ & Berkhamstead & $26 / \mathrm{F}$ & $\begin{array}{l}\text { morphine, } \\
\text { ketamine * }\end{array}$ & - \\
\hline$\# 16$ & 8 & $28 / 07 / 10$ & Ipswich & $32 / \mathrm{M}$ & cannabis * & $\begin{array}{l}\text { failure to use } \\
\text { medication for } \\
\text { preventing seizures }\end{array}$ \\
\hline$\# 17$ & 7 & $21 / 02 / 10$ & Fife (Scotland) & $49 / \mathrm{F}$ & - & $\begin{array}{l}\text { ("underlying health } \\
\text { problems") }\end{array}$ \\
\hline$\# 18$ & 4 & $28 / 10 / 10$ & Northern Ireland & $17 / \mathrm{M}$ & $\begin{array}{l}\text { ("drug } \\
\text { cocktail") }\end{array}$ & $\begin{array}{l}\text { (“drug abuse since } \\
\text { age } 11 ")\end{array}$ \\
\hline
\end{tabular}

Notes - Table excludes suicides, accidental or violent deaths linked to mephedrone.

Estimated Google hits are a measure of the deceased's name linkage to mephedrone and not a measure of the strength of this link or how much traffic or coverage it receives.

** - Mephedrone subsequently reported as toxicological confirmed, and cause of death factor

* - Mephedrone subsequently reported as toxicological confirmed, but not a factor in death

$\$$ - Mephedrone subsequently reported as undetected in toxicological analysis 
Figure 1: Google Trends "mephedrone" 25/02/10

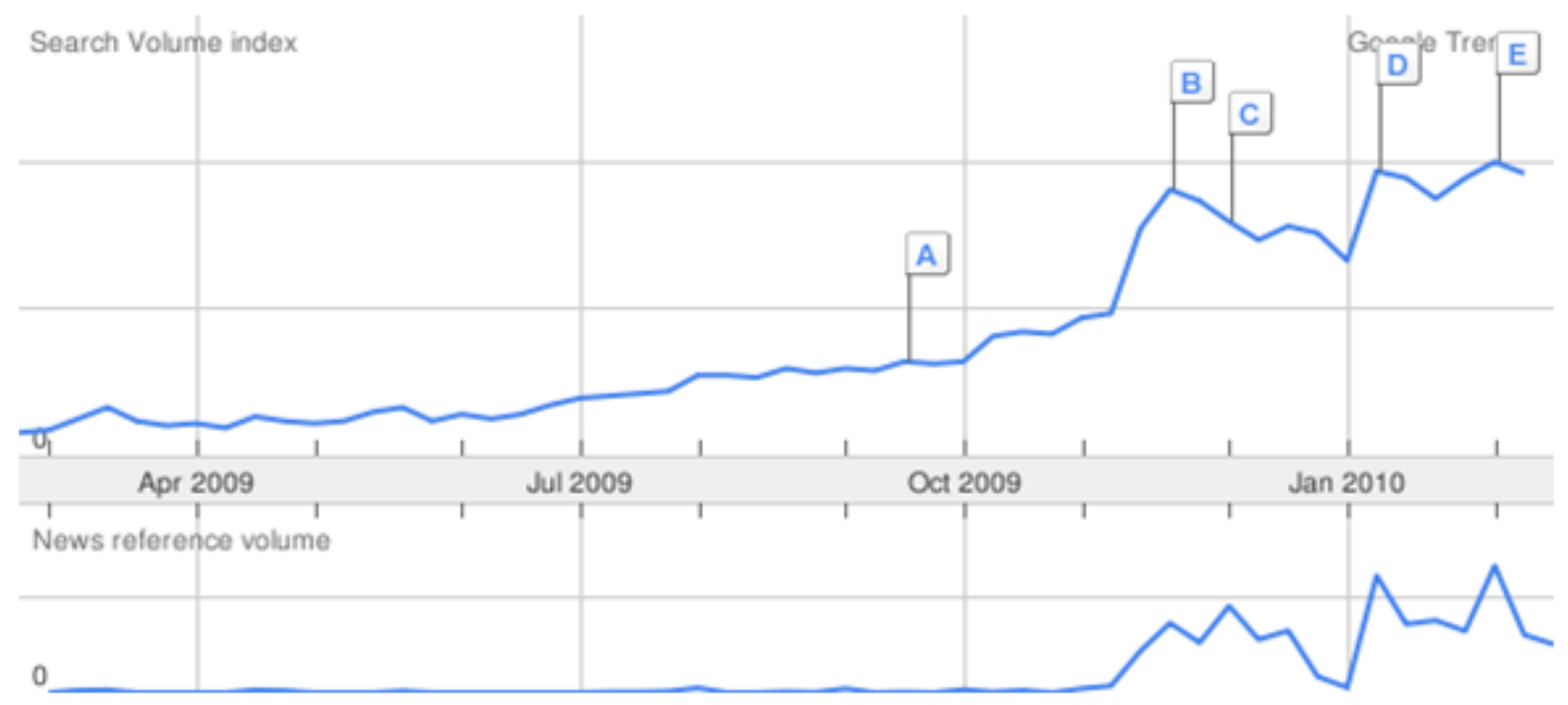

A - New Musical Express "The Ups and Downs of Mephedrone" (23/09/10)

B - Daily Mail "Mephedrone menace the drug that's cheap, as easy to order as pizza... and totally legal" (27/11/09) 
Figure 2: Google Trends "mephedrone" 17/03/10

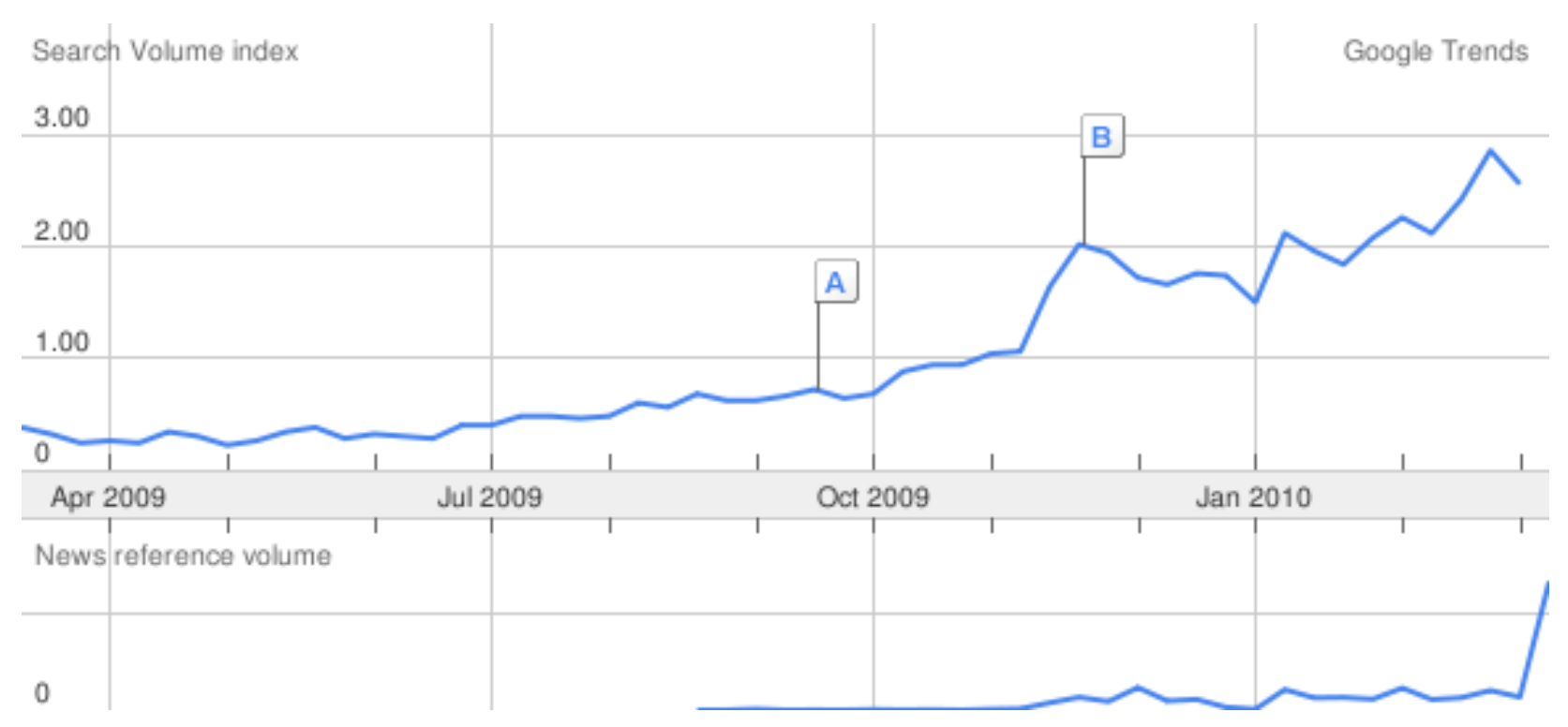

A - New Musical Express "The Ups and Downs of Mephedrone” (23/09/10)

B - Daily Mail "Mephedrone menace the drug that's cheap, as easy to order as pizza... and totally legal" (27/11/09) 
Figure 3: Google Trends "mephedrone" 22/03/10

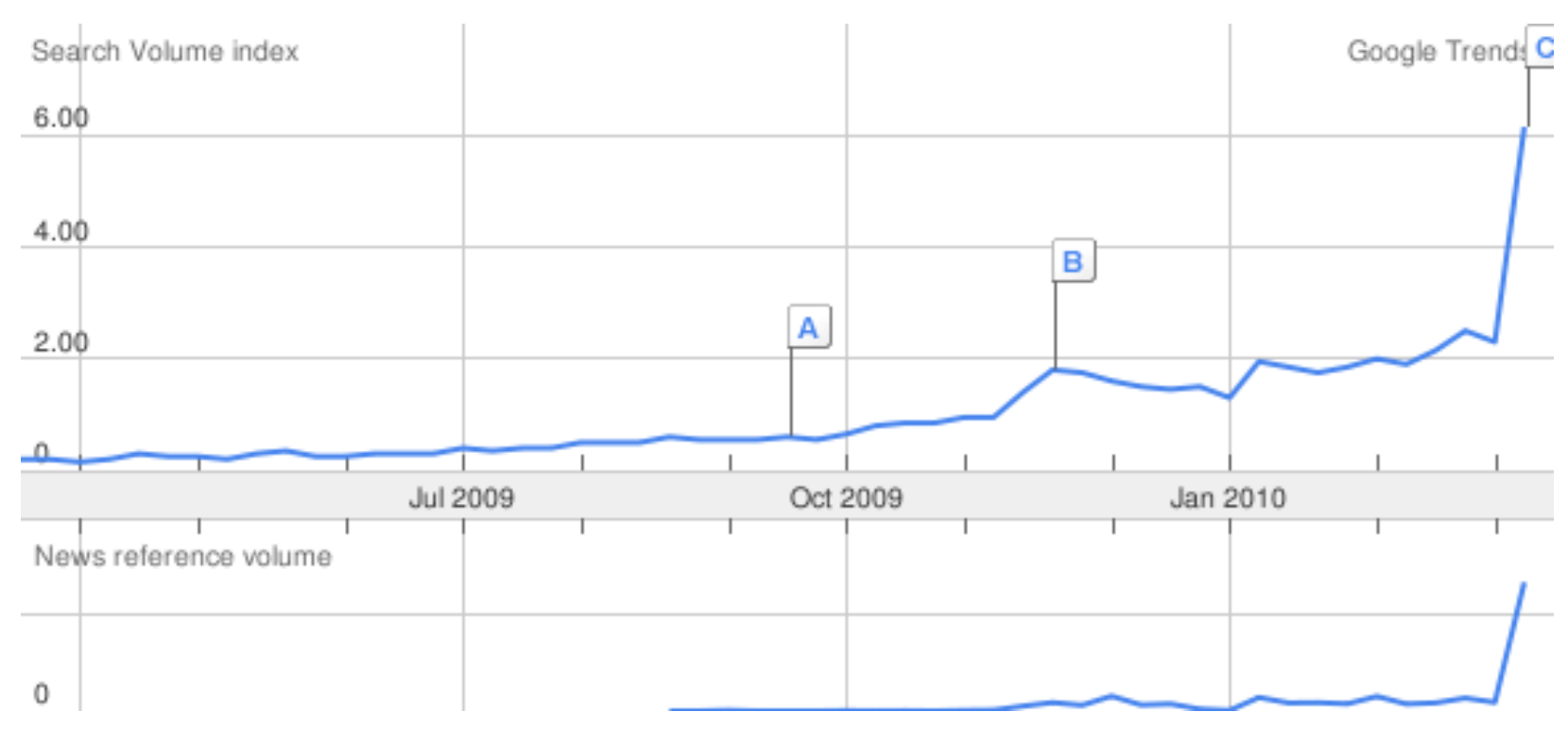

A - New Musical Express "The Ups and Downs of Mephedrone” (23/09/10)

B - Daily Mail "Mephedrone menace the drug that's cheap, as easy to order as pizza... and totally legal" (27/11/09)

C - WalesOnline "3 held over mephedrone deaths" (17/03/10) 
Figure 4: Google Trends "mephedrone buy" 22/03/10

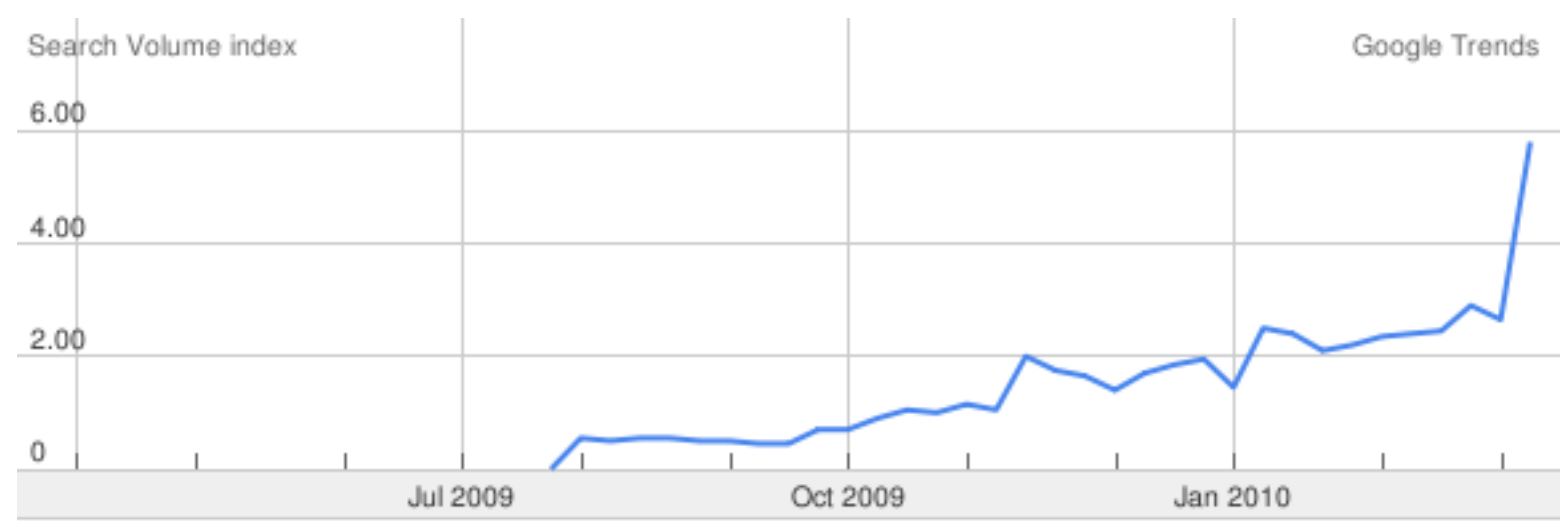

No data available 
Figure 5: Google Insights "mephedrone buy" and "mephedrone deaths" compared 24/03/10

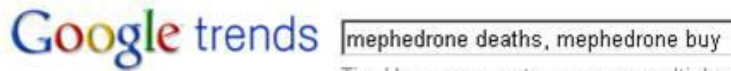
Tip: Use commas to compare multiple search terms

Searches Websites

All regions

mephedrone deaths does not have enough search volume for ranking

mephedrone deaths mephedrone buy

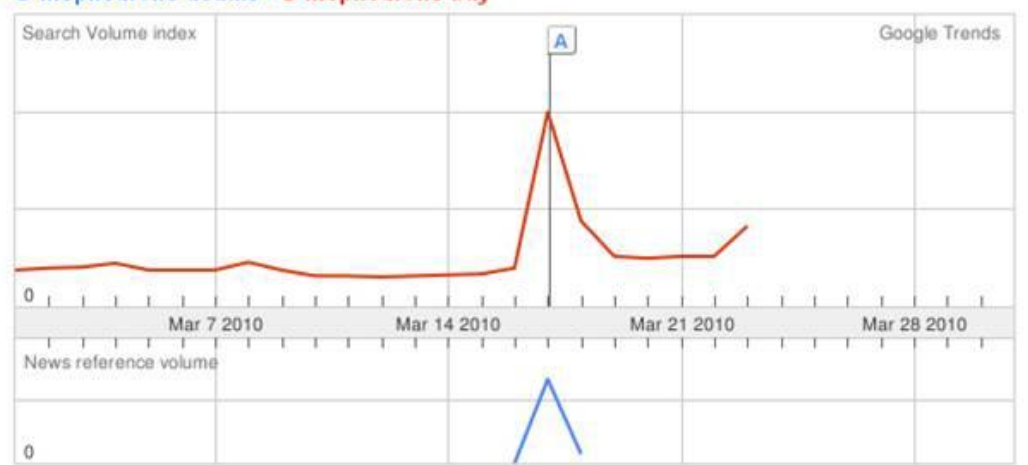

A Three held over 'mephedrone' deaths

WalesOnline - Mar 172010

More news results?

Rank by mephedrone buy

Regions

Cities

1. United Kingdom

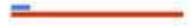

1. Pop

United Kingdom

2. Brentford, United Kingdom

3. London, United Kingdom
Languages

1. English

$\cdot$


Figure 6: Google Trends "mephedrone" 06/09/10

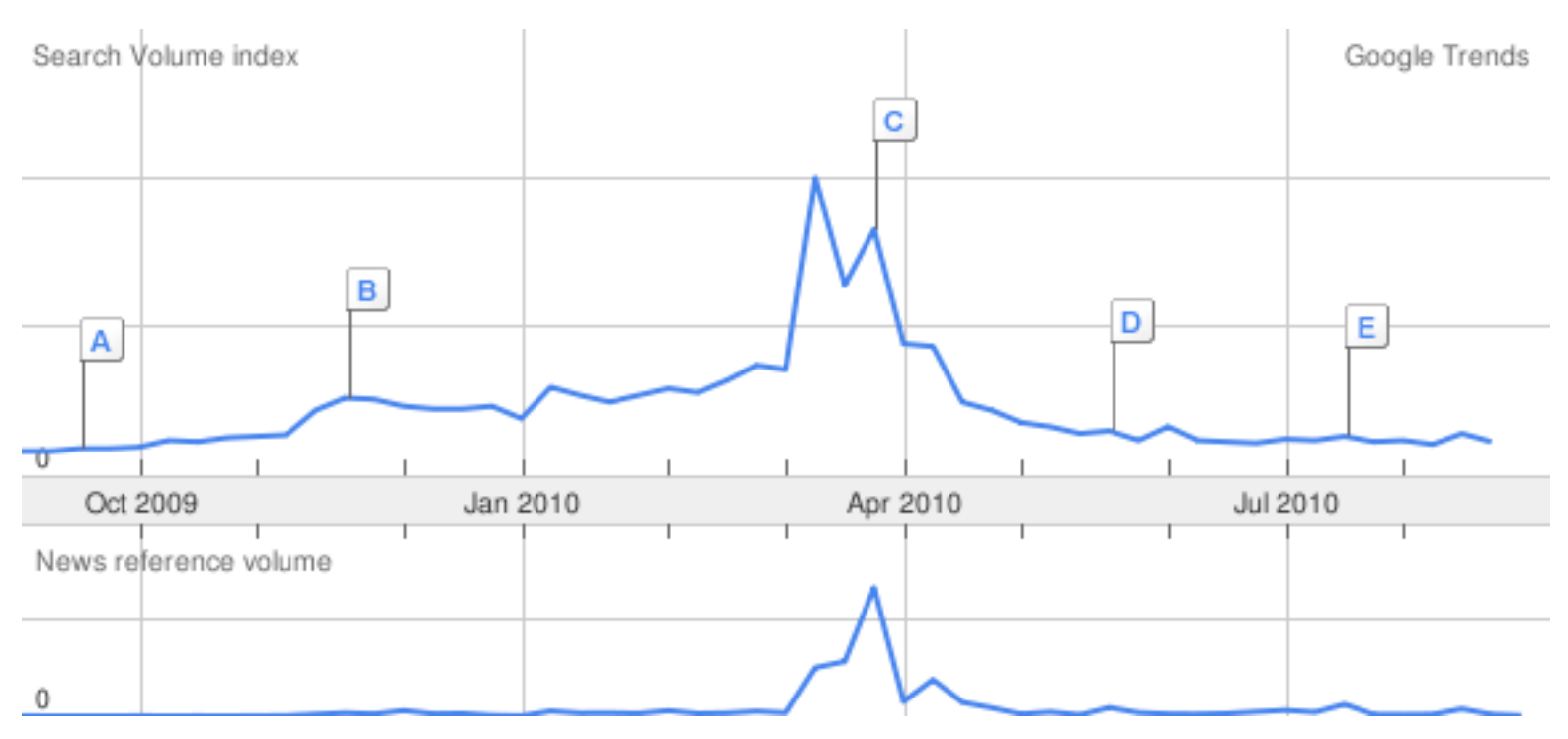

A - New Musical Express "The Ups and Downs of Mephedrone” (23/09/10)

B - Daily Mail "Mephedrone menace the drug that's cheap, as easy to order as pizza... and totally legal" (27/11/09)

C - San Jose Mercury “UK government will ban 'legal high mephedrone” (29/03/10)

D - Telegraph "Professor David Nutt: Police conjecture boosted mephedrone hysteria" $(29 / 05 / 10)$

$\mathrm{E}$ - Independent Inquest hears of teenager's mephedrone tragedy (21/07/10) 